\title{
JUSTINIAN'S WELCOME TO THE CONSTANTINOPLE LAW SCHOOL
}

\section{David Pugsley*}

\section{ABSTRACT}

This paper starts with Justinian's speech welcoming the new first year law students. They will not have to study antiquae fabulae compiled by Tribonian, Theophilus and Dorotheus contrary to the emperor's wishes, but Institutes following his clear instructions. Tribonian, who originally had total delegated authority, was reduced to strict obedience to the emperor's instructions. The antiquae fabulae were preserved by adding them on at the end of the Digest after 5015 , to form titles 5016 and 17. That explains why they have the appearance of having been tacked on at the end, and why they contain so many twin texts when repetitions were prohibited in the Digest but would have been quite suitable in a first year student work.

Keywords: Justinian; Institutes; Tribonian; antiquae fabulae; de verborum significatione; de regulis juris

\section{Imperatoriam $^{1}$}

1. It is good to see so many freshers ${ }^{2}$ keen to study law. ${ }^{3}$

2. And when we had organised the venerable constitutions of the emperors, which were previously in a muddle, and set them out in a clear and methodical order, we

121 Nov 533. This is a speech, oratio nostra (Tanta 11, last sentence).

2 Juventus.

3 Cupida legum.

* Professor, International Faculty of Comparative Law, Strasbourg. 
then turned our attention to the enormous volumes of the old jurisprudence as well. It was a daunting task, but we jumped in at the deep end and, thank heavens, we have already completed it.

3. When, thank God, this was completely finished, ${ }^{4}$ we summoned his Excellency Tribonian, past chamberlain ${ }^{5}$ of our sacred palace, and also Theophilus and Dorotheus, the illustrious scholars. ${ }^{6}$ We already knew from our own experience their legal skill and knowledge, and their loyalty and obedience to our instructions. We told them in no uncertain terms ${ }^{7}$ to compile the Institutes at our command and following our instructions; so you may start studying the law, not from what the ancient jurists said (antiquae fabulae), ${ }^{8}$ but from your splendid emperor, and you may hear and learn nothing that is not useful or is out of place, but only the actual substance of the law. Previously your predecessors only read the imperial constitutions after four years, but you have shown that you deserve the great honour and the great pleasure of studying them straight away, so that both the beginning and the end of the law course are pronounced by the voice of the emperor.

4. So, after the fifty books of the Digest or Pandects, containing the whole of the ancient law (compiled for us by his Excellency Tribonian and other illustrious and brilliant men), we ordered the said Institutes to set out in these four books the basic principles of the whole legal system.

5. They set out briefly both what was previously in force and what was later obscured by disuse and brought back to light by us.

6. They have been compiled from all the Institutes by the ancient authors and especially from our Gaius' commentaries, both his Institutes and his common legal problems, ${ }^{9}$ and lots of other commentaries. Those three wise men presented them to us, and we have read and considered them, and decided to give them exactly the same legal authority as our constitutions.

\section{Peractum.}

5 Exquaestore.

6 Antecessores. Normally translated into modern languages as "professors". But the Justinianic sources have both antecessores and professores. The antecessores were brilliant (facundissimi) and illustrious; the professores were not. The oratio ad antecessores (Omnem) was addressed to them in Latin only, which they all understood; the constitutio ad professores was sent to them in Greek as well, in case they could not understand Latin. In Dedoken the professores are translated into Greek; the antecessores are transliterated, which suggests that they could not be translated. The confusion arose when they became professores constituti, professors designate, in Omnem. Since the antecessores were not translated into Greek, it might be better not to translate them into English either, but to keep the Latin word. Alternatively we might use the English word, "scholars", whose general meaning is clear enough, but whose precise meaning is elusive, just like antecessores.

7 Specialiter.

8 Antiquorum juris auctorum responsa, Cujas.

9 Res cottidianae. 


\section{Deo Auctore $11^{10}$}

And so we order that everything should be governed by those two codices, one of constitutions, the other of jurisprudence abbreviated and compiled in the future codex; ... or if anything else is promulgated by us to take the place of the Institutes (institutionum vicem optinens), so that freshers, having been taught the basics, may be brought more easily to the understanding of the higher learning. ${ }^{11}$

\section{Tanta $11^{12}$}

But we saw that the burden of so much knowledge was too heavy for freshers ${ }^{13}$ standing in the first reception rooms of the laws and in a hurry to enter into their secrets. So we decided that a shorter version ${ }^{14}$ should be prepared ... ${ }^{15}$

And so we summoned Tribonian, the eminent man who was chosen for the government ${ }^{16}$ of the whole work, and also Theophilus and Dorotheus, illustrious men and brilliant scholars, and instructed them to make a separate collection (libris separatim collectis) of the books by the old authors containing the first principles of the laws and called Institutes. Whatever was found in them that was useful and most appropriate and polished in every way and in accordance with modern practice, should be carefully excerpted and re-arranged in four books to set out the basic and elementary principles of the whole learned work; so that freshers could build on them and support the heavier and more detailed rules of law.

1015 Dec 530, addressed to Tribonian, and through him to the other compilers, jubemus igitur vobis.

11 The second half of this text fits very badly with the first. The two codices are there because they set out the whole law; the Institutes, or their replacement, are there because they are useful for students. And the second half does not link grammatically to the first. It would fit much better in Deo Auctore 12: commentaries are forbidden; but quaedam admonitoria are permissible, vel si quid aliud a nobis fuerit promulgatum institutionum vicem optinens. It is perhaps a hasty annotation by Justinian on Tribonian's original draft: the Digest is to be compiled (by the compilers), the Institutes may be promulgated (by Justinian). That does not affect the argument in this article.

1216 Dec 533. This and its Greek version, Dedoken, were speeches, orationes, addressed to the Senate and the whole world (Omnem pr).

13 Homines rudes.

14 Mediocris emendatio.

15 Here there is an extraordinary set of mixed metaphors, which cannot be meaningfully translated and which do not appear in the Greek version in Dedoken:"So that, thereby tinctured and so to speak imbued with the first elements of the whole subject, they might proceed to the innermost recesses thereof and take in with eyes undazzled the exquisite beauty of the law" (Monro). "So that they, receiving a new coloration from it and, so to speak, imbued with the first fruits of the whole subject, might be able to proceed to the innermost parts of it and absorb with eyes undazzled the exquisite beauty of the law" (Watson).

16 Gubernatio. 
We also told them to keep in mind our constitutions, issued for the amendment of the law, and to insert the amendments in the Institutes straight away, to make clear both the previous differences of opinion and the later fixed rules.

The completed work was presented to us and re-read; we gave it our approval because it was not in breach of our instructions. And we ordered that those books should have the force of constitutions, as our speech, inserted as a preface to those books, formally announces.

\section{Who was in charge, Tribonian or Justinian?}

According to the traditional view Tribonian was in charge of everything. He had been a member of the commission for the first Code, and he was the senior member of the commissions for the Institutes, the Digest and the second Code. He was the leading figure in Justinian's law reforms.

The picture in Imperatoriam is rather different. He appears as a brilliant lawyer, but the emphasis is on his loyalty and obedience and on Justinian's commands and authority. Justinian insisted that the students should have his Institutes and not a collection of antiquae fabulae. Presumably Tribonian and his colleagues had produced a collection of antiquae fabulae (we shall come back to this point later), and Justinian overruled them very firmly. It is therefore appropriate to take a fresh look at the question: "Who was in charge?"

In Deo Auctore, the official announcement of the Digest programme in December 530, the position is clear and unambiguous: Tribonian was in charge. He had authority to choose the compilers (he presented them to Justinian for his approval, but this seems to have been a pure formality), and the whole project proceeded under his control (gubernatio) and his supervision (vigilantia). ${ }^{17} \mathrm{He}$ was in charge of the manuscripts and distributed them to the other compilers. ${ }^{18}$ The same idea of gubernatio appears at the beginning of the constitution in the relationship between Justinian and his empire: nostrum gubernantes imperium, governing our empire. Justinian was an absolute ruler, in complete control of the empire. Similarly Tribonian was in complete control of the whole operation, with Justinian's permission, totam rem faciendam permissimus.

In Tanta, the official conclusion of the Digest in December 533, the emphasis has been totally reversed. Tribonian no longer had permission to do what he wished but instructions, omne ministerium huiuscemodi ordinationis imposuimus, to do what the emperor wanted, ut nostrum desiderium adimpleret. Tribonian's gubernatio has gone, so has his vigilantia. It is now Justinian who is vigilant, ${ }^{19}$ asking questions all the

17 Deo Auctore 3.

18 Tanta 17: praebuit.

19 He had previously shown vigilantia in the constitutions: CJ $7311 \mathrm{pr}$. But that was natural in the case of law reform. 
time, semper investigando, and keeping a close eye on everything that is happening, perscrutando.$^{20}$ Tribonian, said Justinian, thought nothing more important or dearer to his heart than the emperor's commands. ${ }^{21}$ This is very much in line with what we have seen in Imperatoriam.

Deo Auctore and Tanta were published together as prefaces to the Digest in 533 and as title 117 in the second Code in 534. It is the natural tendency of lawyers to interpret such documents together to reconcile any differences between them. But "lawyers are no good as historians; they have no sense of time". ${ }^{22}$ They were originally published three years apart, and, as historians, we should consider the possibility that the differences between them were due to events during those three years. ${ }^{23}$

Something must have happened between December 530 and December 533 to cause such a radical change in the management of the project. One possibility is the Nika riots in January 532, when Tribonian was sacked as quaestor and perhaps also as a compiler, so that when he came back he did so on different terms. Another possibility is that Tribonian and the compilers had done something of which Justinian strongly disapproved, causing his change of attitude. That might have been the compilers' collection of antiquae fabulae.

\section{Why did the Institutes start so late?}

It was only after the Digest was completely finished that Justinian summoned the three compilers of the Institutes and gave them their instructions. That is surprisingly late; and indeed Bluhme says: "But it seems that this last piece of information should not be taken absolutely literally, as otherwise the publication of the Digest would certainly have taken place earlier; and Justinian only really talks of the disposal of the main difficulties, namely excerpting all the works and excluding all the obsolete laws." ${ }^{24}$ And he suggested that after book 34 had been completed Tribonian, Theophilus and Dorotheus started to work on the Institutes and left the other compilers to edit the last sixteen books of the Digest on their own. There is no justification for that suggestion in Imperatoriam, which clearly states that everything had been completed. and lists their names. It is generally assumed that they were all there from beginning to end. But Deo Auctore does not give the number or the list, and there is no evidence that they were all there at the beginning. Some may have started later on, like the workers in the vineyard, where all were treated equally at the end: Matthew 20, 1-16.

24 Bluhme (2008): 374-375.
} 
The question is: why did Tribonian and his colleagues not start sooner? Why did Justinian not give them clear instructions to start sooner? He had made it clear in Deo Auctore that he wanted an elementary introduction for the benefit of first year students; and the compilers working on the Sabinianic Mass had read and excerpted all the classical Institutes immediately after the Digests of Julian and Alfenus and related works. They could have started on the Institutes straight away. That would have been quicker and easier for them, and more convenient for their readers and for us. They could have drafted I 41 at the same time as they drafted D 472 . Then they could have had the same definition of furtum in both places instead of two variants: lucri faciendi gratia included in the Digest but omitted in the Institutes. They could have drafted I 43 at the same time as they drafted D 92 . Then they could have had the same account of actiones utiles and in factum in both places instead of the conflict that appears between them.

But Justinian's complaint was not simply about the delay. It was that they had actually produced the wrong thing: they had produced antiquae fabulae, instead of Institutes.

For an explanation we must go back first to Deo Auctore 11. The instructions were not simply to produce a set of Institutes, but to produce something institutionum vicem optinens. Does that mean some sort of Institutes, or something instead of Institutes? Does it mean Institutes (in which case the language is odd) or something other than Institutes?25 Modern translations struggle to find a satisfactory interpretation of vicem: something "to serve the use of" institutes (Monro); something "serving the purpose of" institutes (Watson); something "to replace" the elementary works (Honore); "in forma di" istituzioni (Bianchini). As lawyers we are trained to find the correct interpretation of disputed texts. The question is: what do those words mean? As historians we should consider a different possibility, namely that the words are ambiguous, so that we should ask: what did the writer mean, and what did the reader understand? Justinian clearly thought he was going to get institutes, but perhaps Tribonian meant something other than institutes.

Next we must re-examine Tanta 11. Justinian summoned the three compilers and instructed them to compile a short student-friendly work in four books. In Imperatoriam 3 we are told that he summoned them and instructed them to compile the Institutes. The two accounts overlap in part and diverge in part; and the first question that arises is: are they two accounts of the same event, or accounts of two separate events? For it would not be surprising if Justinian had summoned the compilers more than once during the course of their work.

If there are two accounts of the same event, then, after the completion of the Digest, the compilers were instructed to make a separate collection of the classical institutes, libris separatim collectis. You can imagine the reaction of the compilers: 
"But Justinian we have already done that once in the course of compiling the Digest; do you really want us to go through that process again?! How long is that going to take?" And the phrase libris separatim collectis is odd, as is clear from the modern translations: "to collect the books one by one" (Monro ${ }^{26}$ and Watson); "les livres rassemblés un a un" (Gaurier); "opere raccolte autonomamente" (Bianchini); "Bücher gesondert zu sammeln" (Behrends et al). What does separatim mean? What does it add to collectis? How else do you make a collection? When I pick a bunch of flowers I pick them one by one, but I do not say so.

If there were two separate summonses the text makes good sense. We know that the compilers made a separate collection of Institutes inside the Sabinianic Mass. While many works were grouped by author - Papinian, Modestinus, Pomponius, Javolenus - the Institutes were grouped separately by subject matter. Justinian told the three compilers to make a separate collection of Institutes. It is reasonable to assume that the instruction preceded the performance. In that case Justinian summoned the compilers at least twice, once early in 531 and once sometime in the middle of 533. That is confirmed by an important difference between the two accounts. In Tanta 11, Tribonian still has the gubernatio of the whole operation, and Theophilus and Dorotheus are, as usual, illustrious and brilliant, illustres et facundissimi. In Imperatoriam 3, there is no mention of Tribonian's gubernatio; and the word facundissimi does not appear. The compilers are still clever and knowledgeable, but they are also loyal and obedient. That is in line with the fundamental change between Deo Auctore and Tanta.

The three compilers did not produce the Institutes that Justinian wanted, but something which he described as antiquae fabulae. You can imagine the scene when Tribonian and the other two took the collection to Justinian:

"Justinian, here is the new introductory work which we have just compiled for first year students." And Justinian, glancing at it: "This is not what I wanted. I told you to produce a set of Institutes."

Tribonian, in some trepidation, "No, your Majesty, you told us to produce something instead of the Institutes. Look, here are your instructions in Deo Auctore. They say quite clearly institutionum vicem optinens, and that is what we have done."

Justinian, furious: "That is not what I meant. These are antiquae fabulae. I do not want them. Go away, and compile a set of Institutes. Is that clear?"27

After that Justinian kept a close eye on everything that his loyal and obedient compilers were doing. When the new version was presented to him, he personally read and examined it to make sure that it was in accordance with his instructions, and only then did he give it his approval and the same status as a constitution.

26 Followed by Blume in his translation of CJ 1172.

27 Specialiter mandavimus! 


\section{What were the antiquae fabulae? ${ }^{28}$}

Justinian rejected what he called antiquae fabulae without telling us much about them. But we can deduce something from the words and something from the contrast with the Institutes on which Justinian insisted.

The words, antiquae fabulae, might mean "ancient fables". Peter Birks has "obscure old stories". Bianchini has "chiacchiere degli antichi", ancient gossip or chit-chat. But why should Justinian tell the students that they need not read ancient fables? Had previous students read ancient fables? No, they had read Gaius, and his Institutes were not ancient fables. Had anyone suggested that they should read ancient fables? Had the three compilers made a collection of ancient fables? That is most unlikely. So we need to look to see if there is another, and more plausible, interpretation of the words.

The word, fabula, occurs twice, and only twice, in the Justinianic sources: once here, and once in CJ $74011 \mathrm{~d}$ (18 March 530). Blume translates it as follows: "So no one must interpret that an action ... for theft, robbery or any other personal action has a longer life than thirty years, but it ceases to have life when the period mentioned, after it has accrued and come into existence, has expired and is not brought to life again to be finished after the stated time, according to idle prattle, as, for instance, has been stated in connection with actions for theft." If this is right then fabula means "idle prattle". But it is a very bad translation. It omits ab initio, semel, iteratis and saepe; memoratum tempus appears twice; and the word order is completely distorted. And we may wonder what is the point of the reference to idle prattle?

Here is my translation: "(B)ut it is from the moment when the action first begins (ab initio) and when it has been once (semel) born, and not after it has been re-created over and over again (saepe) by repeated fabulae (iteratis fabulis), as used to be said of theft, that the said period brings it to an end." Now an action cannot be re-created over and over again by repeated idle prattle. We need to find another translation and interpretation of fabula. Looking at other meanings of fabula and related words like fabulor, I suggest the neutral translation "statement". If I tell you that certain things are mine and you have stolen them, time runs from that point, and the action cannot be revived over and over again by repeated statements to the same effect.

We can now return to Imperatoriam 3. If antiquae fabulae means "ancient statements", what the ancient lawyers said, it could refer to something similar to the Digest, with authors' names (inscriptions) and text: in fact "ancient quotations". Is it plausible that the three compilers might have compiled an introductory work for first year students in that way, at the same time as they were compiling the Digest itself,

$28 C f$ Knütel (2013): 169-183. He translates Imperatoriam 3 so that henceforth the students will no longer (hinfort ... nicht mehr) have to study antiquae fabulae, which implies that they had previously had to do so. Actually the text merely says that they will not have to study them, which does not. And he rejects Cujas' interpretation: ab ipso ore principis, non ab antiquorum juris auctorum responsa, without any reason. 
instead of the Institutes? Why not? Did Justinian disapprove of it? Yes, we know that he did: he wanted Institutes in his own name, without inscriptions; imperialis splendor, not antiquae fabulae. He wanted nothing that was not useful, nothing that was out of place in an introductory work (nihil inutile nihilque perperam positum), just the substantive law (quod in ipsis rerum optinet argumentis). The inscriptions were not useful. Why should first year students worry about the names of the classical jurists? Let them just learn the law. (First year students in case-law systems today agree: why do we have to remember the names of the cases? Why can we not just learn the law?)

\section{What happened to the antiquae fabulae?}

Our final question is: (W)hat happened to the antiquae fabulae? Of course, since Justinian had rejected them, they might have disappeared without trace. But one can imagine Tribonian saying to Justinian: "Justinian, we have spent a lot of time and energy preparing these introductory materials. They are really basic and useful. It would be a pity to waste all our hard work. If they cannot be used for first year students, can we put them somewhere else?"

Justinian: "How are you going to do that?"

Tribonian: "We could have a separate publication, diversae fabulae juris antiqui, for example."

Justinian: "That will not work. Deo Auctore 11 said that the whole law should be set out in the two codices, constitutionum and juris enucleati. You cannot have anything else."

Tribonian: "Perhaps we could add them on at the end of the Digest."

Justinian: "You cannot do that. The Digest is already finished. You cannot add anything else now. In any case I told you in Deo Auctore 5, that there should be 50 books. So you cannot have 51."

Tribonian: "But we could add them on at the end of book 50. You said 50 books, but you did not say how long a book should be. Some books are very short, like D 6, because you abolished res mancipi and mancipatio and the actio auctoritatis; some are average; and some are very long: books 40 and 48 are nearly twice as long as the average. We could do the same with book $50 . "$

Justinian (who has many more important things to do): "OK, go ahead."

And there they are. If we look for basic materials which seem to be out of place we can find them in D 5016 and 17: definitions and legal rules. Forget for a moment the twin texts and Bluhme's Masses; forget the details; think of these two titles as a block. The end of the Digest as we have it is most remarkable. If it had ended at D 50 15 there would be nothing surprising. Books 49 and 50 are composed of lots of small titles (18 in book 49, 15 in book 50) on the most miscellaneous and insignificant topics, as if there was nothing important left to say; D 5015 is quite a good place to 
end, with its list of cities in which the jus italicum applies; and if book 50 ended at that point it would be more or less the same length as the average book in the Digest.

And then we have two major titles, by far the longest in the Digest in the number of fragments, apparently of great importance, and which double the length of book 50. This does not look as if it was planned. Those two titles look as if they were tacked on at the end at the last moment. ${ }^{29}$ Digest 5016 is particularly striking because there was already a separate section of book 32 on the meaning of words, which the repetition of Bluhme's Masses shows was intended to be a separate Digest title. And both titles, but particularly 50 17, are remarkable for the number of leges geminatae, which Justinian had expressly forbidden in Deo Auctore. ${ }^{30}$

On the other hand in both titles the fragments, with very few exceptions, follow Bluhme's order, so they must have been drafted at the same time as the rest of the Digest while the compilers were working on the texts in their original order. That means that they were drafted before the completion of the rest of the Digest. ${ }^{31}$ And the question is: Where did they come from? The answer is that they had been drafted by the three compilers as an introductory work for first year students at the same time as, but separately from, the Digest itself. That explains the repetitions. Repetitions were forbidden in the Digest, and between the Digest and the Code; but there was no objection to repetition in the first year introductory work, which was not intended to say something different but to cover the same ground in simpler form, without long factual cases or complicated legal argument. The compilers were expressly told to include references to Justinian's constitutions in the Institutes, which also repeat passages from the Digest, like the definition of furtum, though without the inscriptions. First year students like legal rules without having to work them out from the cases. (That is still true today: why do we have to read the cases? Just give us the rule.)

Justinian insisted on having his Institutes. Tribonian did not want his work wasted. If there was no other possibility it could be added at the end of the Digest, after 50 15. The compilers' antiquae fabulae became the Digest titles 5016 and 17.

\section{Postscript}

There could be no objection to a title on the meaning of words since there was already a section on that in the Digest itself. It was too late to expand book 32,

29 Hofmann 1900: 113-114 n 7, describes them as Anhänge, with an academic origin, but he does not explain where they came from or why they were added.

30 Stein 1966: 122-123: "The precise function of the last title of the Digest is not clear today and was probably not clear to the compilers themselves ... The compilers no doubt attributed to the title a certain ornamental function. It rounded off the Digest in a neat and conclusive manner. Yet 211 ornaments are a little excessive even for Byzantines."

31 Verrey 1973: 103: "Que cette ordre soit demeuré parfaitement immuable démontre bien que les titres 16 et 17 furent rédigés longtemps avant l'achèvement du Digeste lui-même, à un moment où les compilateurs avaient sous les yeux les textes extraits dans une forme peu ou pas élaborée." 
because the Digest had already been completed (up to the end of 5015 ), but there was no objection to adding it on at the end. The situation with regard to 5017 is less clear. It is just a collection of miscellaneous rules. It is possible that Justinian did not want them but Tribonian did.

But, as we know, 5017 was added as well. It was unlikely that Justinian would read the whole Digest and notice it. There was, however, a problem with Tanta 8c, which records the contents of book 50. It was quite likely that Justinian would read that; at any rate it was a serious risk, enough to worry Tribonian. All translations are the translator's interpretation of his original text. Let us, therefore, look at some of the modern translations of Tanta 8c. The translations by Monro, Watson, Bianchini and Gaurier all omit any reference to regulae juris and 50 17. The Bianchini translation is particularly striking because it ends with the words significato delle parole. The German translation, on the other hand, includes them: und das, was die alten Juristen über die Bedeutung der Wörter gefunden und was sie als Regel definiert haben.

It seems that some people can see 5017 in Tanta, 8c, and others cannot. How are we to explain this extraordinary phenomenon? The answer lies in the words quaeque regulariter definita near the end of the text. Monro ${ }^{32}$ moves them to the beginning and translates: "whatever else we find devised by the ancients and strictly laid down ..."; Watson varies it slightly: "whatever else has been found in the ancient works or has been laid down by statutes ..."; Bianchini has: "ogni altra disposizione e ogni definizione formulata dagli antichi ..."; and Gaurier says: "Tout le reste qui a ete trouvé dans les anciens livres et qui a été régulièrement défini ..."

The German translation faithfully follows the order of the Latin text, ${ }^{33}$ and recognises that quaeque regulariter definita refers to 50 17. Similarly Peter Stein translates: "whatever is expressed in the form of a regula." 34

It seems that those who look for 5017 in Tanta 8c, find it; but those who are not looking for it do not find it. We might ask: who is right? What do those words mean? Or we may ask: what did Tribonian mean, and what did Justinian understand by those words? If Justinian had rejected the regulae as antiquae fabulae, he would not be expecting to find them and, if he read the text, might not have noticed them. Tribonian, who wanted to include antiquae regulae, intentionally chose words which did include them but which could easily be overlooked. Hence the rather obscure wording which carefully avoids the word antiquae. The Greek version in Dedoken is much clearer: "and what has been said by the jurists of old on the maxims of law." ${ }^{35}$ Justinian would have noticed that; but, while he might have read the Latin

32 Followed by Blume in his translation of CJ 1172.

33 So the last word of the Latin text is perfectus, the last word of the German translation is vollendet.

34 Stein 1966: 115.

35 Watson edition, translation by Olivia Robinson. 
version before he approved it, it was most unlikely that he would proof-read the Greek version.

\section{Summary}

1. Who was in charge, Tribonian or Justinian? Answer: Tribonian at the beginning, Justinian at the end. The incident of the Institutes may have been the turning point.

2. Why did the Institutes start so late? Answer: because the three compilers had been making a collection of what Justinian called antiquae fabulae and it was only when that was rejected by Justinian that they started on the Institutes.

3. What were the antiquae fabulae? Answer: a collection of quotations from the ancient jurists, with inscription and text, giving pithy definitions and legal rules suitable for first year students.

4. What happened to the antiquae fabulae? Answer: They were tacked on at the end of the Digest after D 5015 to form the last two titles, namely 5016 and 17.

\section{BIBLIOGRAPHY}

Bluhme, Friedrich (1820) "Die Ordnung der Fragmente in den Pandectentiteln. Ein Beitrag zur Entstehungsgeschichtliche Rechtswissenschaft" in Zeitschrift für geschichtliche Rechtswissenschaft, vol 4, 257-472

Blume, Fred Heinrich (2008) Annotated Justinian Code (Wyoming)

Hofmann, Franz (1900) Die Compilation der Digesten Justinians (Vienna)

Knütel, Rolf (2013) “Constitutio Imperatoriam, 3: fabulis oder tabulis" in Liber Amicorum Guido Tsuno (eds) Fritz Sturm, Philip Thomas, Jochen Otto \& Hikaru Mori: 169-183 (Frankfurt)

Stein, Peter (1966) Regulae Juris (Edinburgh)

Verrey, Olivier (1973) Leges Geminatae (Lausanne) 